Rigó Csaba Balázs - Tóth András

\title{
A digitális szolgáltatási adó szimbolikus jelentốsége és annak gyakorlati következményei
}

Összefoglaló: A digitális szolgáltatásokat kínáló világcégek jellemzően úgy nőttek nagyra, hogy a közterhek viseléséhez nem feltétlenül járulnak hozzá abban az országban, ahonnan a bevételeik megteremtéséhez szükséges adatvagyon származik. Jelen tanulmány célja annak bemutatása, hogy a digitális szolgáltatást nyújtó világcégek megadóztatása nem csak adóbevétel-növelési, de szimbolikus szempontból is jelentőséggel bír. Az „új olajat” jelentő adatok kiaknázásából ezért méltányosan részesednie kellene azon államoknak is, amelyek polgárainak adatai felhasználásával a digitális világcégek jelentős bevételre tesznek szert. A politikai, jogszabályi környezet elemzése és az állambölcseleti elméletek áttekintése révén arra jutottunk, hogy ebben a szimbolikájában is jelentős kérdésben sem valószínú az EU-szintű egységes fellépés sikere és éppen ezért tagállami, nemzeti szintú intézkedésekre lehet szükség.

Kulcsszavak: digitális adó, adat, hegemónia, digitális világcégek

JEL-KódoK: H26, K20, K21, K34

DOl: https://doi.org/10.35551/PSZ_2020_4_5

A digitális szolgáltatások magukba foglalják az adatalapú információs és kommunikációs technológiai szolgáltatásokat, az online platformokat és a platformalapú szolgáltatásokat. Ezen a területen olyan világméretű vállalatok jöttek létre, amelyek sok esetben nemcsak egyeduralkodók a saját piacukon, de a világgazdaság legnagyobb cégei közé is emelkedtek. Közös bennünk, hogy sikerüket az online térnek és az adatok növekvő jelentőségének kö-

Levelezési e-cim: rigo.csaba@gvh.hu toth.andras@kre.hu szönhetik. Felmerülhet persze, hogy a siker az adatok mellett mennyire múlik a feldolgozás minőségén (Colangelo, Maggiolino, 2017), de a német és francia versenyhatóság közös tanulmánya szerint van az a szintje az adattömegnek, amely mellett (hasonló méret nélkül) amúgy jó minőségű adatelemzések sem fognak versenyképesen müködni (Autorité de la Concurrence, Bundeskartellamt, 2016).

A világ legértékesebb öt vállalata az Apple, Google, Microsoft, Amazon, Facebook közül az eredendően eszközgyártási profillal is rendelkező Apple és a szoftvergyártó Microsoft- 
on kívül mindegyik cég szolgáltatása lényegében kizárólag a virtuális térnek és adatoknak köszönhetően létezik (Forbes, 2020). Ezek a cégek már messze meghaladták saját jelentőségüket, mert közben a társadalmat, a gazdaságot is jelentősen érintő változásokat hoztak. A reklámköltés 30-40 százaléka ma már az online térben történik és ennek fele-kétharmada a Google-nál, Facebook-nál csapódik le (MRSZ, 2020). Egy átlagos felhasználó napi 58 percet tölt a Facebook-on és 53 percet az Instagram-on (BroadBand Search, 2020; Marketing Land, 2019), miközben tovább nő a harc a felhasználók figyelméért, az így elöállt adatokért, mert ezekkel füthető a bevételt hozó reklámpiac.

A digitális szolgáltatásokat kínáló világcégek közben úgy nőttek nagyra, hogy a közterhek viseléséhez nem feltétlenül járulnak hozzá abban az országban, ahonnan a bevételeik megteremtéséhez szükséges adatvagyon származik. A transznacionális cégek e helyett inkább letelepednek azokban az országokban, ahol az adóoptimalizálásukat csúcsra járatva a legnagyobb adókedvezményt kapják és lényegesen kevesebb adót fizetnek versenytársaiknál. A jelenség különösen tetten érhető az Európai Unióban, ahol az említett világcégek -kihasználva az EU lassan reagáló bürokratikus intézményrendszerét - könnyen egyeznek meg a kiszemelt tagállammal, hiszen egy esetleges tiltott állami támogatás bizonyítására is csak hosszas bírósági procedúra végén van remény.

Jelen tanulmányban azt mutatjuk be, hogy a digitális szolgáltatást nyújtó világcégek megadóztatása nem csak adóbevétel-növelési, de szimbolikus szempontból is jelentőséggel bír. Ez a szimbolikus szempont azonban azzal a gyakorlati következménnyel jár, hogy - úgy tünik - ebben a témában is erősen kérdéses az EU-szintű fellépés sikere, és éppen ezért a tagállami, nemzeti szintű intézkedésekre lehet szükség.

\section{A DIGITÁLIS VILÁGCÉGEK MINT AZ ADÓELKERÜLÉS BAJNOKAI}

A nagy multinacionális vállalatok alaphelyzetben hozzáférnek azokhoz a kreatív adózási tanácsokhoz, amelyek segítik őket az adó optimalizálásában. Az OECD 2018. évi becslése alapján a világ összes országát tekintve a kormányzatok éves bevételkiesése 2015-ben legalább 100-240 milliárd dollár volt, ami a globális társasági adóbevétel 4-10 százalékának felel meg (OECD, 2020a). Ismert a „dupla ír” vagy a „holland szendvics” példája: csak egy ír leánycég kellett, aki elutalta a bevételt egy holland, még munkavállalókat sem foglalkozó társaságnak, aki visszautalta egy ír tulajdonú offshore cégnek (Tepper, Hearn, 2019). Ez a körülmény arra vezethető vissza, hogy a globális kereskedelemben nem a cégek, hanem az államok versenyeznek (a befektetőkért) többek között ilyen adókedvezményeknek köszönhetően. Másrészt, a digitális szektor jellemzői tovább könnyítik az adókijátszást. A jelenlegi adószabályok száz évesek és ezért a fizikai jelenléten alapulnak, így a fizikai jelenlét biztosít lehetőséget az országok adóztatási jogkörének gyakorlására (Állami Számvevőszék, 2020). A digitális szolgáltatást nyújtó világcégek működésbeli jellemzőikből fakadóan azonban tényleges fizikai jelenlét nélkül is képesek adott országban szolgáltatást nyújtani, illetve az ott megtermelt hozzáadott érték segítéségével nyereségre szert tenni. Ezen digitális szolgáltatást nyújtó világcégek tehát még könnyebben kerülik meg a helyi adófizetési kötelezettségeket, mint az amúgy ebből a szempontból eleve kreatív multinacionális társaságok. Miközben a nemzeti cégek és kkv-k megfizetik az adókat, addig ezek a digitális szolgáltatást nyújtó világcégek évente 60 milliárd euró adó megfizetését kerülik meg (Tepper, Hearn, 2019). Az Európai Bizottság szerint a digitális szolgáltatást nyújtó vállalatok adóterhelése a fele a hagyományos vállala- 
tokénak, amely csak tovább növeli a feszültségeket (Európai Bizottság, 2018a).

\section{A DIGITÁLIS SZEKTOR MEGADÓZTATÁSÁNAK SZIMBOLIKUS JELENTŐSÉGE}

Tisztázni szükséges, hogy a teljes modern gazdaság gyakorlatilag digitális abban az értelemben, hogy nincs már olyan ágazata a gazdaságnak, amely ne használna digitális adatokat (Állami Számvevőszék, 2020; IMF, 2018). Éppen ezért indokolt megkülönböztetni a szűken vett digitális gazdasági tevékenységet, magát a digitális szektort.

A digitális szolgáltatást nyújtó világcégek megadóztatása nemcsak azért indokolt, mert bizonyos országok sokkal kevesebb adóbevételhez jutnak globális és határokon átnyúló digitális szolgáltatást nyújtó vállalatok tevékenysége után, mint ami méltányos lenne (Állami Számvevőszék, 2020). A digitális szolgáltatást nyújtó világcégek megadóztatásának ugyanis szimbolikus jelentősége is van. Adó nélkül eleve nincs társadalmi lét, és minden nagy társadalmi fordulópont egyúttal adózási forradalom is [lásd: amikor a francia forradalmi küldöttgyűlés megszavazza a nemesség és papság előjogainak eltörlését és a mindenkire vonatkozó közteherviselést (Piketty, 2015)]. A digitális szektor megadóztatása is ilyen fordulópontot jelent a következők szerint.

2017-et írtunk, mikor az Economist először írta le, hogy az adat az „új olaj” (The Economist, 2017). Annyiban semmiképpen nem tévedett, hogy az olajhoz hasonlóan az adatokat is ki kell termelni és fel kell dolgozni. Egyes elemzők úgy vélik, hogy éppen azért tudott sikeresebb lenni a Facebook a MySpace-nél és a Google a Yahoo!-nál, mert keresleti szempontból nagyobb vonzerőt képviselő megoldásokkal álltak elő (Boutin, Clemens, 2017). Ha ugyanis az adat az „új olaj”, akkor természete- sen jelentős hatalmat tudhat magáénak az, aki birtokolja az adatot. Ezzel kapcsolatban a globális nagyhatalmak eltérő stratégiát folytatnak. Kína az adatvagyonát lényegében nemzeti stratégiai értéknek tekinti, teljes állami felügyelet érvényesül ezen a téren, míg az USA-ban ezen a téren is a magánszféra dominál jelentős piaci koncentráltság mellett (Európai Bizottság, 2020a). Európa ebből a szempontból azonban vesztésre áll, mert azt látjuk, hogy az európai adatvagyon lényegében az USA-ba vándorol, az amerikai digitális szolgáltatásokat nyújtó világcégekhez (Chaire Castex de Cyberstrategie, 2020).

$\mathrm{Az}$ adatok USA-ba vándorlásával azonban önmagában még nem lenne gond, ha annak lenne ellentételezése. Itt utalunk arra, hogy a múltban az olaj nem csak a cégeket, de azokat az államokat is gazdaggá tette, amelyek területén azt kiaknázták. Vagyis az adott ország vagyonának felhasználásával elért bevétel megadóztatásán keresztül biztosítható volt, hogy az adott nemzet méltányosan részesedjen a saját területi erőforrásainak felhasználásából. Ebből a szempontból a digitális korban késve ébredt az EU, mert csak az elmúlt években merült fel a digitális szolgáltatásokat nyújtó világcégek megadóztatása. Éppen ezért külön fájdalmas, hogy az EU képtelen volt az USA-val szemben egységes EU-szintű digitális adó bevezetését elérni (Euractiv, 2019a). Nem véletlen és kifejezetten beszédes, hogy az USA kereskedelmi háborúval fenyegeti (Tax Foundation, 2020a) a nagy amerikai digitális szolgáltatást nyújtó cégek európai megadóztatását. Meg kell jegyezni, hogy az USA következetesen tiltakozik a digitális világcégek más európai szabályozási kezdeményezéseivel szemben is (PaRR Global, 2020).

Hiába a globális kapitalizmus, minden nemzetnek csak maga felé húz a keze. A globális kapitalizmus sem szól másról, mint a versengésről általában: vannak nyertesek és vesztesek. A globális kapitalizmus nagy paradoxonja, 
hogy elnevezésével szemben igenis nemzeti érdekek mozgatják, és a győztest is nemzeti szinten hirdetik ki. A nemzetek és érdekeik mindig is ott voltak a globális kapitalizmus hátterében, mert a nemzetállami szint továbbra is a világ működésének egyik legfontosabb dimenziója maradt annak történeti, nyelvi, kulturális, jogi és az egy nemzethez való tartozás pszichés természete miatt (Egresi, Pongrácz, Sziget at al., 2016).

Világkereskedelmi hegemóniára alapvetően más népek erőforrásainak kiaknázásával és felhasználásával lehet eljutni. Ennek eszköze lehet a háború, gyarmatosítás, rabszolga-kereskedelem, vagy békeidőben a tőke, az emberek és újabban a kibertámadások, vagy egyszerüen az adatok elszívása, amelynek kiváló eszközei az amerikai adatmonopóliumok. Persze nem feltétlen magasztos nemzeti elvek, hanem az elitek (politika-gazdaság) nemzeti szintű öszszefonódása miatt alakult ki az, hogy cégek és nemzetek adott esetben egymást támogatva vesznek részt a globális kereskedelem formájában megnyilvánuló hegemóniaharcban. ${ }^{1}$ Az USA-ban az adatmonopóliumok nem véletlenül voltak lényegében érintetlenek. 2012ben a Federal Trade Commission például fontolgatta a Google elleni antitröszt-fellépést, de végül politikai okokból letett erről, hiszen $\mathrm{Ba}$ rack Obama újraválasztási kampányának második legnagyobb támogatója éppen a Google volt (Tepper, Hearn, 2019). De Trump elnök is ostorozza az EU-t az amerikai adatmonopóliumok elleni határozott fellépés (védekezés) miatt (Politico, 2019). Ehhez képest mindenképpen figyelemre méltó, hogy 2020. október 20-án az USA Szövetségi Igazságügyi minisztere és még 11 republikánus állam föügyésze pert indított a Sherman Act 2. $\$$ alapján a Google ellen és kérik a bíróságtól a feldarabolását. ${ }^{2}$

Hogy az amerikai kormányzatnak miért nincs ellenére az amerikai digitális világcégek európai sikere, arra rámutatott az Európai Bíróság 2020 júliusában egy előzetes döntésho- zatali eljárás során hozott ítélete, ${ }^{3}$ amelyben kinyilvánította, hogy az EU-USA adatvédelmi pajzs keretrendszere már nem érvényes mechanizmus az EU adatvédelmi követelményeinek való megfelelés érdekében, amikor személyes adatokat továbbítanak az Európai Unióból az Egyesült Államokba. Az Európai Bíróság szerint ugyanis nem biztosított az EU általános adatvédelmi rendelet $\left(\mathrm{GDPR}^{4}\right)$ és az EU Alapjogi Charta által személyes adatok vonatkozásában rögzített védelmi szint, mert az EUadatok jogosultjainak nem áll rendelkezésre hatékony védelmi mechanizmus, ha az amerikai felhasználás sérti az EU jogában létező és elismert jogaikat, például az adataik amerikai kormányzati felhasználása esetén.

Ezek az amerikai digitális világcégek tehát tovább erősítik az amerikai hegemóniát a világban, miközben az EU adatvédelmi szabályozása és adózási szabályai lényegében semmilyen védelmet nem kínáltak az EU számára ebben a harcban.

\section{EURÓPA KIRABLÁSA}

Az európai adatok USA-ba áramlása nem véletlen annak fényében, hogy az EU a világ legnyitottabb gazdasága (Európai Bizottság, 2020b). Az külön fájdalmas, hogy az európai adatvagyon elvesztése az állítólag fejlett európai adatvédelmi szabályozás mellett történt meg. Az adatvagyon elvesztése súlyos hátrányba hozta az EU-t például a mesterséges intelligenciáért (MI) folytatott nemzetközi versenyben is. Amíg az Amerikai Egyesült Államokban a nagyvállalatok jelentős összegeket fektetnek az MI fejlesztésébe (az észak-amerikai beruházások szintje 12,1-18,6 milliárd euró), addig az európai magánberuházások értéke (2016-ban összesen 2,4-3,2 milliárd euró) e téren jelentösen elmarad (Európai Bizottság, 2018b).

Felmerül, hogy az Európai Bíróság már említett 2020. júliusi ítélete végre véget vet az eu- 
rópai adatvagyon USA-ba hurcolásának. Ezt vetíti előre a Facebook ellenreakciója is, hiszen 2020 szeptemberében a Facebook bejelentette, hogy jogi lépéseket tesz az ír adatvédelmi hatóság azon döntése ellen, amely megtiltja a Facebook-nak, hogy az eddig használt mechanizmus alapján adatokat továbbítson az Európai Unióból az Egyesült Államokba (Reuters, 2020). A helyzet azonban az, hogy ez az EUbírósági döntés formális okokból nyilvánította érvénytelennek a Bizottság adatvédelmi pajzs határozatát, mert a Bíróság szerint jogellenesen vonta le azt a következtetést, hogy az EUból USA-ba került adatok esetében biztosított az GDPR és az EU Alapjogi Charta által személyes adatok vonatkozásában rögzített védelmi szint. Ugyanakkor ez a döntés tartalmában semmit nem vetít előre az európai adatvagyon megőrzését illetően, mert az adatok USA-ba továbbítása kapcsán minimális standardként azokat az EU-szabályokat és védelmi szinteket állítja be, amelyek azonban alábbiak szerint eleve nem elégségesek.

A GDPR - úgy tűnt - megjeleníti majd az EU hangját az adatokért folytatott küzdelemmel is jellemzett új digitális világgazdaságban. Az EU szimpatikusan, értékalapúan közelítve kívánta erősíteni az egyéni jogokat a személyes adatokkal való gazdálkodás terén. De ez olyan jól sikerült, hogy közben saját gazdasági adattere kialakítása ellen hatott, amely fóleg az MI kifejlesztése és felhasználása terén folytatott nagy nemzetközi versenyfutásban bizonyult károsnak (Tóth, 2019; Európai Bizottság, 2018b), hiszen a GDPR szabályozási rendszere akadályozza az adatcsere- és hozzáférési megállapodásokat. A GDPR 4. cikk (2) bekezdése alapján ugyanis az adatmegosztás is adatkezelésnek minősül, így csak a 6. cikk (1) bekezdésbe foglalt feltételekkel valósítható meg, különleges személyes adatok esetében pedig a követelmények a 9. cikk alapján még szigorúbbak. A jogbiztonság szempontjából így a GDPR-ra figyelemmel is kedvezőbb, ha az adatmegosztásnak törvényi alapja van, föleg, mert amúgy versenyjogi következményei is lehetnek (versenykorlátozó megállapodás vagy erőfölénnyel való visszaélés, miként a német Facebook döntés ${ }^{5}$ mutatja). Az, hogy a GDPR nem elégséges az adatáramlás előmozdítása érdekében, már a bizottsági szakértő anyagában is felmerült az adathordozhatósággal összefüggésben, amely csak a múltbeli adatok vándorlására kínál megoldást, de nem biztosítja a folyamatos adatmegosztást (Crémer, Montjoye, Schweitzer, 2019).

Másfelől bár a GDPR kifejezetten rögzíti: a természetes személyek számára biztosítani kell, hogy saját személyes adataik felett maguk rendelkezzenek, ez a rendelkezési jog könnyen erodálhatónak és megkerülhetőnek bizonyult. Az adatalapú online szolgáltatások igénybevételekor a felhasználónak ugyan el kell fogadni az adatvédelmi szabályzatot és az általános szerződési feltételeket, ezek azonban gyakran olyan hosszan és bonyolultan vannak megfogalmazva, hogy a legtöbb fogyasztó számára nehézséget okoz a megértésük, vagy egyszerủen sajnálják az időt az elolvasásukra (OECD, 2016). Egyes kutatások szerint éves szinten több mint 200 órát is igénybe venne, ha egy átlagfelhasználó minden ilyen online tranzakciós helyzetben gondosan végigolvasná ezeket a tájékoztatásokat (OECD, 2016). Ez egyértelműen rámutat arra, hogy ezek az eszközök valójában alkalmatlanok a fogyasztói információs aszimmetria csökkentésére, ezért sürgeti az OECD is a valós, fogyasztókat védő, tájékozott döntéshozatalt előmozdító megoldások bevezetését (OECD, 2016). A NAIH egy 2015-ös határozatában (NAIH, 2015) is megállapította, hogy a bonyolult adatkezeléshez kapcsolódó hozzájárulás kapcsán a tájékoztatás módját a tartalomhoz kell igazítani. A tájékoztatónak a NAIH szerint strukturáltnak, könnyen áttekinthetőnek kell lennie, amelyet elsődlegesen a szöveg megfelelő szintű tördelésével, felsorolások alkalma- 
zásával lehet elérni. Kérdés, hogy megvalósítható-e ez, és egyáltalán megoldást jelent-e a korábban vázolt problémákra. A megoldást csak olyan adatvédelmi szabályozás biztosíthatná, amelynek célpontjában maga az „aki kimarad, az lemarad” üzleti modell áll, amely nem kínál kiutat a felhasználónak a személyes adata átadása alól.

Mivel az EU adatvédelmi védelmi szintje az említett elveket nem tükrözi és nem követi, így az annak való megfeleléssel megvalósult adattovábbítás lényegében az európai adatvagyon kizsákmányolását teszi csak lehetővé. Az európai adatvédelem erősítésén túl azonban a jelen tanulmány tárgyát képező adózás területén is intézkedéseket kellene tenni.

\section{EURÓPA GYARMATOSÍTÁSELLENI SZABÁLYOZÁSI UTÓVÉDHARCAI}

A globális gazdaságban az említettek szerint létező nemzetek közötti versenyt jól jellemzi a periféria-félperiféria-centrum felosztás, ahol a centrumot az innováció és magas hozzáadott értékủ munka, a perifériát pedig a centrum általi kizsákmányolás, illetve az ellene való védekezés (bezáródás) határozza meg. A félperiféria pedig jellemzően a nyitás és zárás változtatásával igyekszik kezelni a kihívást (Egresi, Pongrácz, Szigeti, Takács, 2016). Lehet szépíteni, hogy az EU innovációja a digitális globális kapitalizmusban maga a szabályozás (Euractiv, 2019b), de a hegemóniaharcban ez inkább a periféria védekező reflexének tűnik.

Az EU eleve nem igazán jól felvértezett a hegemónia-harcban, mert szemben az USAval híján van az egységes nyelvi, kulturális egy nemzethez való tartozás pszichés érzéseknek, amelyek a hegemóniaharcban a nemzetállamokat fütik. Így kérdéses, hogy olyan szimbolikus ügyben, mint az amerikai adatmonopóliumok megadóztatása képes lesz-e egységes fellépésre. Az eddigi tapasztaltok nem túl biztatóak, ha csak az adózást nézzük. Meg kell azért jegyezni, hogy más európai szabályozási területek is csalódást keltettek már a digitális szektor káros hatásaival szembeni harcban. Az adatvédelem és a jelen tanulmány tárgyát képező adózás mellett mindenképpen meg kell említeni a versenyjogot, ahol európai szinten csak 2019ben indultak el azok a folyamatok (föleg tagállami példák alapján), amelyek végre érdemi lépésnek tekinthetők. ${ }^{6} \mathrm{Az}$ Európai Bizottság hozzájárulásának köszönhető, hogy a Google a DoubleClick 2008-as felvásárlása nyomán megkerülhetetlen online hirdetési szereplővé vált (Autorité de la Concurrence, 2018), hiszen ez a fúzió tette lehetővé számára a böngészési és keresési információk összekapcsolását, amelyről a Bizottság úgy vélte, hogy nem reális veszély.?

Adózási fronton veszteség, hogy az EU Törvényszéke 2020 júliusában hatályon kívül helyezte az EU Bizottság döntését, amelynek értelmében az Apple-nek 13 milliárd euró meg nem fizetett adót kellett volna az ír költségvetésbe visszautalni tiltott állami támogatás miatt, mondván nem bizonyítható az ír kormány részéről a kivételezés. ${ }^{8}$

$\mathrm{Az}$ EU a digitális adózás kérdését eddig egy ideiglenes és egy hosszú távú megoldással próbálta kezelni. Az EU-szintű digitális adóval az EU egyrészt mérsékelni kívánta az egységes piac széttöredezettségének kockázatát, amelyet az egyoldalú nemzeti intézkedések megjelenése jelentett, másrészt olyan intézkedéseket akart előre vetíteni, amellyel segíthetné az adóalaperózió és nyereségátcsoportosítás (úgynevezett BEPS) keretében folytatott globális vitát azzal, hogy az EU elkötelezettségét és elgondolásai irányát lerögzíti. Az Európai Bizottság ezért 2018. március 21-én beterjesztette a digitális gazdaság tisztességes adóztatásáról szóló csomagot (Európai Bizottság, 2018b). A Bizottság ideiglenes javaslata egy tanácsi irányelvre vonatkozott, amely megadóztatná olyan jelenleg nem adózott digitális szolgáltatások által gene- 
rált bevételeket, mint például amelyek az online hirdetési felület értékesítéséből, közvetítői tevékenységekből (amelyek megkönnyítik az áruk és szolgáltatások értékesítését), valamint a felhasználói adatok értékesítéséből folynak be. Csak olyan vállalkozásokra vonatkozott volna az adó, amelyek teljesítik a következő küszöbértékeket: a teljes éves világbevétel meghaladja a 750 millió eurót, és az összes éves uniós bevétel az 50 millió eurót. A Bizottság egységes 3 százalékos kulcsot javasolt azon digitális szolgáltatások nyújtásából származó bevételekre, amelyek esetében a felhasználói értékteremtés alapvető jelentőségű. A javasolt hosszú távú megoldása az OECD-BEPS kezdeményezés fényében meghatározta volna a ,jelentős digitális jelenlét" fogalmát, amely akkor állna fenn, amikor a tagállam területén nincs fizikai jelenlét, ezért így az adóztatás jogának alapját képezheti digitális szolgáltatást nyújtó vállalkozások esetében. A vállalkozások adóztathatók lennének, ha egy adóévben megfelelnek a következő kritériumok legalább egyikének: az éves bevétel meghaladja a 7 millió eurót; több mint százezer felhasználó van egy tagállamban; több mint 3000 vállalkozások közötti szerződés a digitális szolgáltatásokkal kapcsolatban. A nyereségarányos hányada ekkor adóztatandó abban a tagállamban, amelyben a vállalkozás adóköteles digitális jelenléttel rendelkezett. $\mathrm{Az}$ arány egyenértékủ lenne a tagállamban valós fizikai jelenléttel rendelkező adóalanyokkal szemben alkalmazottal. Az adó azon társasági adófizetőkre is vonatkozna, amelyek az EU-n kívüli joghatósággal rendelkeznek, és amelyekkel nem kötött kettős adóztatás elkerüléséről szóló megállapodást az a tagállam, amelyben jelentős digitális jelenléttel bíróként azonosították az adózót.

A körülmények azonban az USA-nak kedveznek, hiszen adózási kérdésben az EU csak a tagállamok egyhangú döntésével határozhat. Márpedig, ha a globális kereskedelemben a tőkéért az államok adókedvezményekkel verse- nyeznek, akkor egyáltalán nem lehet azon csodálkozni, hogy az egységes EU-s digitális adó többek között éppen Írország miatt bukott meg 2019 végén (Euractiv 2019a). A hivatalos tájékoztatás szerint a tagállamok megvárják az OECD-ben 2020 végére e téren várható fejleményeket (Európai Unió Tanácsa, 2019). De ne legyenek illúzióink: az USA az OECD keretein belül e téren zajló kezdeményezést kötelező érvénnyel nem támogatja, lényegében a világcégekre bízná, hogy részt vesznek-e az új adózási rendszerben (Bloomberg, 2020). 2020. július 15-én az EU Bizottság egy új adócsomagot fogadott el, amelynek részeként a digitális platformokra is kiterjeszti az adózási átláthatóságra vonatkozó uniós szabályokat annak érdekében, hogy azok a szereplők, akik termékek vagy szolgáltatások platformokon történő értékesítésével jutnak jövedelemhez, szintén méltányosan kivegyék részüket az adófizetési kötelezettségből (Európai Bizottság, 2020c). Az új javaslat értelmében automatikussá válna a tagállamok közötti információcsere az eladók online platformokon termelt bevételeire vonatkozóan. Lényeges, hogy a javaslat nem terjed ki a digitális adózással kapcsolatos kérdésekre, mert a tekintetben az EU továbbra is az OECD 2020 végi fejleményeire vár.

A digitális szektor megadóztatásának kérdése az OECD-ben a szervezet által 2013-ban indított és már említett BEPS-kezdeményezésbe integrálódott 2015-ben. A 15 különálló cselekvési területet (köztük a digitális szektort) magába foglaló OECD-BEPS kezdeményezés célja, hogy felszerelje a kormányokat az adókikerülés leküzdéséhez szükséges nemzeti és nemzetközi eszközökkel. Az OECD két pillért javasolt a kialakult helyzet kezelésére (OECD, 2020b). Az első pillér az adójogok (nexus) újraelosztására fókuszál, amely túlnyomórészt a fizikai jelenlét helyett az értékesítésen alapulna. Az új nexus akkor jönne létre, amikor egy vállalkozásnak tartós és jelentős mértékủ jelen- 
léte van az adóilletőség gazdaságában, például a fogyasztókkal való interakció és elkötelezettség révén. A fizikai jelenléttől való függés elkerülése érdekében a nexus piaci bevételi küszöbön alapulna. Miután megállapításra kerülne, hogy egy országnak joga van adóztatni egy nem rezidens vállalkozást, az egységes megközelítés javaslatot tenne az adott joghatóságra elosztott nyereség arányának meghatározására is. A második pillér, amelyet „globális bázis-erózió elleni javaslatnak” (GloBE) is neveznek, tartalmazná a nyereség olyan országokba való áthelyezése gyakorlatából eredő kockázatok mérséklésére irányuló intézkedéseket, amely országokban a multinacionális vállalkozásokra nem, vagy nagyon alacsony adók vonatkoznak. A GloBE a minimális adómérték befizetésének biztosítására összpontosít, célja a nyereségátcsoportosításra való ösztönzés csökkentése, és korlátot szab az adók közötti versenyre.

\section{TAGÁLLAMI KEZDEMÉNYEZÉSEK A DIGITÁLIS ADÓ BEVEZETÉSÉRE}

Miután az EU-szintü fellépés sikere erősen kétséges, így az 1 . táblázatban szereplő EUtagállamok (nem először a digitális gazdaság kihívásaival kapcsolatban ${ }^{9}$ ) saját kezdeményezés alapján a Bizottság előzőekben ismertetett rövid távú javaslatát adaptálták vagy azt fontolgatják (KMPG, 2020),

Az EU-javaslathoz képest a táblázatban szereplő tagállamok nem változtattak a világméretű küszöbön, a nemzeti küszöböt nyilván igyekeztek a saját méretükhöz igazítani (Európai Unió Tanácsa, 2019).

Ezek azok a tagállamok tehát, amelyek az EU-javaslathoz hasonlóan megadóztatnák az olyan jelenleg nem adózott digitális szolgáltatások által generált bevételeket, mint amilyenek például az online hirdetési felület értékesítéséből, közvetítői tevékenységekből (amelyek megkönnyítik az áruk és szolgáltatások értékesítését), valamint a felhasználói adatok értékesítéséből folynak be. Ausztria csak a digitális hirdetési bevételt adóztatja 5 százalékkal 2020. január 1-jétől, ha a cég világméretű bevétele a 750 millió eurót és az ausztriai online hirdetési tevékenységből származó bevétel pedig a 25 millió eurót eléri.

Az USA bejelentette, hogy valamennyi felsorolt tagállammal szemben vizsgálatot indított és Franciaországgal szemben a szövetségi kormányzat már javasolta is 2,4 milliárd USD értékű francia árura 100 százalékos büntetővám bevezetését (Tax Foundation, 2020b).

Magyarországon a reklámadót a reklámadóról szóló 2014. évi XXII. törvény vezette be 2014-ben több progresszív adókulccsal, 0 százalék és 50 százalék között. Egy 2015ös Bizottsági vizsgálat megállapította, hogy ez az adó állami támogatásnak minősül, mert progresszív adókulcsok különbséget tesznek a magas reklámbevételű vállalkozások és az alacsony reklámbevétellel rendelkező vállalkozások között, és méretük alapján szelektív előnyt biztosítanak a kisvállalkozások számára. ${ }^{10} \mathrm{Ma}$ gyarország ezért a progresszív kamatlábakat két kamatlábbal cserélte ki: 0 százalékos rátára a 100 millió forint alatti bevételrészre, és 5,3 százalékos kulcsra az efölötti részre esőt, amit később 7,5 százalékra emelt. 2017-ben az Európai Törvényszék ${ }^{11}$ azonban megsemmisítette a Bizottság ezen határozatát, mert nem látta bizonyítottnak, hogy a reklámadó progresszív szerkezete miatt szelektív előny, vagyis állami támogatás állna fenn. Ennek ellenére Magyarország mégis felfüggesztette az adót 2022. december 31-ig. Ezzel a magyar adónemmel összefüggésben közben az Európai Bíróság is megnyilvánult. A 2020. március 3. ítéletben ${ }^{12}$ a Bíróság kimondta, hogy egy olyan tagállami szabályozás, amely a valamely másik tagállamban letelepedett reklámszolgáltatókat a reklámadó-kötelezettségük tekintetében bejelentkezési kötelezettség alá veti, nem ellentétes 


\section{TAGÁLLAMI DIGITÁLIS ADÓK}

\begin{tabular}{|c|c|c|c|c|}
\hline \multirow[b]{2}{*}{ Ország } & \multirow[b]{2}{*}{ Hatályos } & \multirow[b]{2}{*}{ Adó mértéke } & \multicolumn{2}{|c|}{ Adóalanyok } \\
\hline & & & $\begin{array}{c}\text { Világméretö } \\
\text { bevételi kïszöb }\end{array}$ & $\begin{array}{l}\text { Nemzeti bevételi } \\
\text { kïszöb }\end{array}$ \\
\hline Belgium & javaslat & $3 \%$ & $\begin{array}{c}750 \text { millió euró } \\
\text { digitális szolgáltatásból }\end{array}$ & $\begin{array}{c}5 \text { millió euró } \\
\text { digitális szolgáltatásból }\end{array}$ \\
\hline Csehország & 2021 & $\begin{array}{l}5 \% \\
\text { kb. } 188 \text { ezer euró feletti } \\
\text { adatmegosztási és } \\
\text { hirdetési bevétel felett, } \\
\text { közvetító szolgáltatók } \\
200 \text { ezer felhasználótól }\end{array}$ & $\begin{array}{c}750 \text { millió euró } \\
\text { teljes }\end{array}$ & $\begin{array}{l}\text { kb. 3,7 millió euró } \\
\text { digitális } \\
\text { szolgáltatásokból }\end{array}$ \\
\hline Egyesült Királyság & 2020. április 1. & $2 \%$ & 500 millió font & 25 millió font \\
\hline Franciaország & $\begin{array}{l}\text { 2019. január } 1 . \\
\text { visszamenőleg }\end{array}$ & $3 \%$ & $\begin{array}{c}750 \text { millió euró } \\
\text { teljes }\end{array}$ & 25 millió euró \\
\hline Olaszország & 2020. január 1. & $\begin{array}{c}3 \% \\
\text { a világméretú bevétel } \\
\text { azon részére, amely } \\
\text { Olaszországból származik }\end{array}$ & $\begin{array}{c}750 \text { millió euró } \\
\text { teljes }\end{array}$ & $\begin{array}{c}5 \text { millió euró } \\
\text { digitális szolgáltatásból }\end{array}$ \\
\hline Spanyolország & javaslat & $3 \%$ & $\begin{array}{c}750 \text { millió euró } \\
\text { teljes }\end{array}$ & $\begin{array}{c}3 \text { millió euró } \\
\text { digitális szolgáltatásból }\end{array}$ \\
\hline
\end{tabular}

Forrás: KPMG, 2020

a szolgáltatásnyújtásnak az EUMSZ 56. cikkben biztosított szabadságával. Ezzel szemben a Bíróság megállapította, hogy a szolgáltatásnyújtásnak az EUMSZ 56. cikkben biztosított szabadságával ellentétes a szabályozás azon része, amely azt írja elő, hogy a Magyarországtól eltérő másik tagállamban letelepedett olyan szolgáltatásnyújtókkal szemben, amelyek nem tettek eleget a bejelentkezési kötelezettségüknek, és amelynek következtében néhány nap alatt egymást követően több mulasztási bírság kerül kiszabásra, amelyek halmozott összege elérheti a több millió eurót. Ennek oka a Bíróság szerint, hogy a szabályozás nem biztosítja az e bírságok halmozott összegét megállapító határozat elfogadását megelőzően az ilyen szolgáltatók számára a kötelezettségeik teljesítéséhez szükséges időt, illetve, hogy az észrevételeiket megtehessék.

\section{A DIGITÁLIS SZOLGÁLTATÁSI ADÓ BESZEDÉSE}

A digitális szolgáltatási adó beszedése kétség kívül kihívás elé állítja az adóztatni kívánó államot akkor, ha az adóalany az országban nem rendelkezik illetőséggel. Márpedig a digitális szolgáltatásnyújtásnak éppen ez az egyik legfőbb jellemzője, hogy nem kell az országban fizikailag jelen lenni ahhoz, hogy jövedelmet termeljenek. A külföldi illetőségű adóalanyok 
tehát a helyibevétel-alapú adókötelezettséget így könnyedén, következmények nélkül megkerülhetik. Azonban éppen a magyar tapasztalatok szolgálnak érdekes tanulságokkal e téren. Magyarország ugyanis 2014-ben a reklámadóról szóló 2014. évi XXII. törvénnyel bevezetett reklámadó keretében az online közzétett hirdetésekből származó bevételre is adót irányzott elő, amely tetemes bírság mellett előírta a közzétevőknek, hogy regisztrálják magukat a NAV-nál, ha Magyarországon nem rendelkeznek adóilletőséggel. A Google-t - miután ennek a regisztrálási kötelezettségének nem tett eleget - a NAV megbírságolta, amellyel szemben a Google jogorvoslattal élt a magyar bíróság előtt. Vagyis úgy tűnik, hogy éppen a nagy digitális szolgáltatást nyújtó világcégek azok, amelyek kényesen ügyelnek a reputációjukra (OECD, 2014), és nem engedik meg maguknak, hogy csak azért kivonják magukat egy nemzeti jogi kötelezettség alól, mert jogilag helyben nem lehet velük szemben fellépni. Bár ez azt jelenti, hogy kisebb, föleg EU-ban nem letelepedett digitális szolgáltatást nyújtók figyelmen kívül hagyhatják az adókötelezettséget, de éppen a legnagyobb bevételre szert tevők nem. Meg kell jegyezni, hogy a Gazdasági Versenyhivatalnak is hasonló tapasztalatai vannak versenyügyekben, mert a Facebook is befizette a rá kirótt 1,2 milliárd forint bírságot, miközben magyarországi jelenléttel nem rendelkezik (Növekedés.hu, 2020).

Ráadásul, amennyiben Magyarországon egy EU-ban amúgy letelepedett vállalkozás nyújt digitális szolgáltatást, akkor a rá kirótt adó behajtása kapcsán irányadó a Tanács 2010/24/ EU-irányelve az adókból, vámokból, illetékekből és egyéb intézkedésekből eredő követelések behajtására irányuló kölcsönös segítségnyújtásról. Vagyis az EU adóhatóságai közötti szabályozott együttműködés révén a Magyarországon kivetett adót az adófizetésre kötelezett illetősége szerinti EU-tagállam adóhatósága magyar kérésre beszedi.
Mindezeken túl a magyar reklámadóról szóló törvény egy további biztosítékot is kínál az adó beszedésére. A törvény (lásd 2 . $\$$, (2) bekezdés) ugyanis kimondja, hogy a reklám megrendelőjét terheli adófizetési kötelezettség, kivéve, ha a megrendelő a közzétevőtől kapott igazolás alapján bizonyítja, hogy a közzétevő az adót megfizeti (ideértve azt az esetet is, ha a közzétevő igazolt felhívására a megrendelőnek a közzétevő az igazolást nem adja ki).

A reklámadóról szóló törvény további előírásai is megfelelő alapot kínálnak egy magyarországi digitális szolgáltatási adó bevezetésére/ kiterjesztésre. A törvény előírja, hogy egy önbevallási rendszeren keresztül a Magyarországon online reklámot közzétevők értesítsék a NAVot (vetessék nyilvántartásba magukat), hogy digitális szolgáltatási adó (dsza) fizetésre kötelesek Magyarországon, illetve az adóév végén nyújtsanak be dsza-bevallást. Az Európai Bíróság az előzőekben ismertetett Google versus NAV magyar ügyben 2020 márciusában az EU jogával összhangban lévőnek találta a magyar reklámadóról szóló törvény azon előírását, amely egy másik tagállamban letelepedett reklámszolgáltatót a reklámadóalanyiságuk tekintetében magyarországi bejelentkezési kötelezettség alá veti.

A felsoroltakon túl érdemes egy további adóelkerülési biztosítékot is beiktatni a szabályozásba: ha a pénzügyi beszámoló készítésekor összevont alapon kezelendő vállalatcsoport egyik jogalanya adóköteles szolgáltatást nyújt egy harmadik fél számára, azonban a szolgáltatás ellenértékét a csoport egy másik jogalanya szedi be, akkor ez esetben úgy kelljen tekinteni, hogy az ellenértéket az adóköteles szolgáltatásokat nyújtó jogalany kapta meg. Ez a rendelkezés egy biztosíték lehetne, amely megakadályozza, hogy az adóköteles szolgáltatásokat nyújtó (az ilyen szolgáltatásokból származó bevételekhez azonban az ugyanazon csoporthoz tartozó másik jogalanyon keresztül hozzájutó) jogalanyok kivonják magukat a dszá-ra vonatkozó kötelezettség alól. 


\section{ÖSSZEGZÉS}

A digitális szolgáltatási adó jelentősége túlmutat azon, hogy a multinacionális nagyvállalatok szokásosan nagyobb erőforrást képesek mozgósítani az adóoptimalizálásra. A digitális szolgáltatást nyújtó világcégek ugyanis úgy is képesek jelentős bevételt elérni egy országban, hogy ott fizikailag nincsenek jelen, így képesek megkerülni a száz éve létező adószabályokat, amelyek a tényleges fizikai jelenlét alapján biztosítják az adóztatás lehetőségét. Ezek a digitális szolgáltatást nyújtó világcégek közben jelentős társadalmi és gazdasági változásokat indítottak el, miközben a legtöbb érintett ország közterheinek viseléséből nem veszik ki a részüket. Közben a bevételeiket olyan új típusú nyersanyagból nyerik ki, mint az adott ország polgárainak adatai. Az adatvagyon elvesztése különösen fájdalmasan érintette az EU-t, amelynek nyitott gazdasága eddig teljesen védtelennek bizonyult. Még az európai adatvédelmi szabályok sem tudták elejét venni, hogy a XXI. század legfontosabb nyersanyaga az adat, az EU-ból az USA-ba vándoroljon. Közben az EU fut a pénze után, és például a mesterséges intelligencia kapcsán kibontakozó nemzetközi versenyben most próbálja az ehhez szükséges adatterét kialakítani, miközben e téren az USA és Kína már régen lekörözte. Ha az adat az „új olaj”, akkor analógiaként nem az a gond, ha az adatvagyon elhagyja az országot, hanem hogy az abból származó haszonból a forrásország nem részesedik méltányosan. A digitális adó szimbolikájában legalább ezt kifejezi. Az persze nem véletlen, hogy az EU képtelen volt az USA-val szemben az egységes digitális adót bevezetni. Egyrészt tagállamai versenyeznek a befektetőkért és éppen olyan adókedvezmények nyújtásával teszik, amelyek csak tovább erősítik ezeket a világcégeket és nem minden tagállamnak áll érdekében egy ilyen EU-szintű adó bevezetése. Másrészt az, hogy USA kereskedelmi háború- val fenyegeti a digitális adót bevezető vagy azt fontolgató európai országokat, ami csak azt támasztja alá, hogy a digitális szolgáltatást nyújtó amerikai vállalatok az amerikai hegemónia zászlóvivői lettek a XXI. századra. Az agy- és tőkeelszívás mellé tehát az adatelszívás is felzárkózott.

Ebből a szempontból az EU a periféria sorsára jutott, hiszen nem maradt számára más, mint a perifériára jellemző védekezés. Hiába igyekszik szépíteni az EU, hogy a saját innovációja egyben szabályozás is a digitális korban, még ha így is lenne, akkor sem igazán sikeresek az utóvédharcok. Az EU-szintű digitális adó elbukott, a fake news-ok ellen eddig nem sikerült hatékony jogi eszközt találni (Európai Bizottság, 2018c), a GDPR-ról kiderült, hogy az nem teljesítette be a várakozásokat, a versenyjog eszközei pedig eddig felemás, néhol csalódást keltő eredményre vezettek. Az eddig elért eredmények alapvetően tagállami szinten vagy nemzeti összefogásnak köszönhetően mutathatók fel, mint például a fogyasztóvédelem terén. Persze az, hogy az EU nem sikeres a hegemónia-harcban az egyáltalán nem meglepő. Egységes identitás, nyelv, kultúra, egyszóval pszichés összetartó erő nélkül nem is lehet ebbe a háborúba menni. Marad a tagállami szintű védekezés és reakció. Ez a digitális adóval kapcsolatos szimbolikus megfontolás gyakorlati következménye.

Általában persze az adónak gyakran van szimbolikus jelentősége. Nagy társadalmi fordulatok sokszor adózási fordulatok is a történelemben (például az Aranybulla által adott adómentesség a nemességnek, vagy a 48-as magyar törvények az általános közteherviselés bevezetéséről). A digitális adó gondolata azt üzeni, hogy a XXI. század új nyersanyagának kiaknázásából az érintett nemzetek is részesedni kívánnak. Azok az európai tagállamok, amelyek a kereskedelmi háborút is kockáztatva felvállalták a digitálisadó bevezetését, jelentős szimbolikus lépést is tettek azon kívül, 
hogy adóbevételeiket okosan növelik. Magyarországnak is érdemes megfontolnia, hogy felzárkózzon ezekhez az országokhoz. Főleg, hogy a reklámadóról szóló 2014. évi XXII. törvény jó alapot kínál a digitális szolgáltatási adó magyarországi bevezetésére/kiterjesztésé- re/felélesztésére. Bár 100 százalékos beszedési biztonságot jelen tudás szerint lehetetlen elérni, a legnagyobb technológiai cégek esetében a releváns magyar hatósági tapasztalatok alapján lehet sikereket elérni az adóbeszedés területén is.

\section{JEGYZETEK}

1 A hegemónia tehát kevésbé az államon alapszik, hanem inkább „a nemzetközi társadalmi kapcsolatok komplexumára támaszkodik, amelyek összekapcsolják a különböző országok társadalmi osztályait", ami kifejezetten a transznacionális tőkés osztály kialakulásában érhető tetten. (Cox, Robert, W. 1993: Gramsci, Hegemony and International Relations: An Essay in Method. In: Stephen Gill (ed.) Gramsci, Historical Materialism and International Relations. Cambridge, Cambridge University Press)

2 Department Files Complaint Against Google to Restore Competition in Search and Search Advertising Markets: https://www.justice.gov/ opa/pr/justice-department-sues-monopolistgoogle-violating-antitrust-laws

3 Bővebben lásd: C311/18, Data Protection Commissioner v Facebook Ireland Ltd ECLI:EU: C:2020:559

4 Az Európai Parlament és a Tanács (EU) 2016/679 rendelete (2016. április 27.) a természetes személyeknek a személyes adatok kezelése tekintetében történő védelméről és az ilyen adatok szabad áramlásáról, valamint a 95/46/EK rendelet hatályon kívül helyezéséről (általános adatvédelmi rendelet), OJ L 119, 2016. 05. 04., 1-88. oldal

5 Bundeskartellamt prohibits Facebook from combining user data from different sources. https:// www.bundeskartellamt.de/SharedDocs/Meldung/
EN/Pressemitteilungen/2019/07_02_2019_ Facebook.html

${ }^{6}$ Bővebben lásd: a Digital Services Act kezdeményezését, a New Competition Tool-ra vonatkozó bizottsági javaslatot, az Amazon, Facebook és Google ellen indult eljárásokat, amelyek alapvetően a német versenyhatóság Facebook döntése hatására ihlették meg az Európai Bizottságot. https://ec.europa.eu/commission/presscorner/ detail/mt/ip_19_4291; https://www.reuters.com/ article/us-eu-facebook-antitrust/eu-antitrustregulators-raise-more-questions-about-facebooksonline-marketplace-idUSKBN21P22J; https:// www.ft.com/content/a6183776-1a74-11ea-97dfcc63de1d73f4; CNBC (2020) Google says it will pay some news publishers to license content, bowing to regulatory pressure https://www.cnbc. com/2020/06/25/google-will-pay-some-newspublishers-to-license-content.html

7 Bővebben lásd: COMP/M.4731, Google/ DoubleClick, 340., 363.

8 Bővebben lásd: T-778/16, Ireland v Commission, T-892/16, Apple Sales International and Apple Operations Europe v Commission

9 Erre példa az online platformok kapcsán megvalósított koordinált tagállami fogyasztóvédelmi fellépés az Airbnb (2018-ban), közösségi média (szintén 2018-ban) és in-app vásárlások (2014ben) ügyében. 
${ }^{10}$ Bővebben lásd: Európai Bizottság, SA.39235 (2015/C) (ex 2015/NN) sz. állami támogatás Magyarország. A Magyarország által bevezetett reklámadó. Brüsszel, 2015.03.12 C(2015) 1520 final. https://ec.europa.eu/competition/elojade/ isef/case_details.cfm?proc_code=3_SA_39235
${ }^{11}$ Bővebben lásd: T-20/17, Magyarország kontra Európai Bizottság ECLI:EU:T:2019:448

${ }^{12}$ Bővebben lásd: C-482/18, Google Ireland Limited kontra Nemzeti Adó- és Vámhivatal Kiemelt Adó- és Vámigazgatósága ECLI:EU:C:2020:141

\section{IRODALOM}

Boutin, X., Clemens, G. (2017). Defining „Big Data" in Antirtust. CPI: Antitrust Chronicle, http://dx.doi.org/10.2139/ssrn.2938397

Colangelo, G., Maggiolino, M. (2017). Big Data as Misleading Facilities. In: European Competition Journal, Forthcoming Bocconi Legal Studies Research Paper No. 2978465. https://ssrn. com/abstract $=2978465$ és

https://doi.org/10.1080/17441056.2017.1382262

Crémer, J., Montjoye, Y.A., Schweitzer, H. (2019). European Commission: Competition Policy for the digital era (final report), pp. 8

Egresi K., Pongrácz A., Szigeti P., Takács P. (2016). Államelmélet, SZE DF ÁJK Jogelméleti Tanszék, Győr, 247. oldal

Piketty, T. (2015). A tỏke a 21. században. Kossuth Kiadó, Budapest

Tepper, J., Hearn, D. (2019). The Myth of Capitalism, Monopolies and the Death of Competition. Wiley, pp. 93

Tóтн A. (2019). Mesterséges intelligencia szabályozásának paradoxonja és egyes jogi vonatkozásainak alapvető kérdései. In: Infokommunikáció és Jog 3-9. oldal

Vestager, M. (2020). New competition tool will allow EC to go after tacit collusion - ICN 2020. In:
PaRR Global. https://app.parr-global.com/intelligence/ view/intelcms-ftqd22?utm_source=Notifications \& utm_medium=Email\&utm_campaign=Alert\&utm_ term $=5$ bacfdb $9952447001 \mathrm{~d} 4 \mathrm{ea} 316$

Állami Számvevőszék (2020). Elemzés a digitális gazdaság megadóztatásának aktuális kérdéseiről, a modern gazdasághoz illeszkedő új uniós adószabályokról értékelő elemzés figyelemmel a terület ellenőrizhetőségére.

Autorité de la Concurrence (2018). L`Autorité rend son avis sur la publicité en ligne. https://www. autoritedelaconcurrence.fr/fr/communiques-depresse/lautorite-rend-son-avis-sur-la-publicite-enligne

Autorité de la Concurrence, Bundeskartellamt (2016). Competition Law and Data p. 12

Bloomberg (2020). U.S. Still Wants Optional OECD Tax Plan-But Don't Call It That (1). https://news.bloombergtax.com/daily-tax-reportinternational/u-s-still-wants-optional-oecd-taxplan-but-dont-call-it-that

BroadBand Search (2020). Average Time Spent Daily on Social Media (Latest 2020 Data). https:// www.broadbandsearch.net/blog/average-daily-timeon-social-media

Chaire Castex de Cyberstrategie (2020). Les flux de données en Europe, massivement captés par les 
États-Unis. http://www.cyberstrategie.org/?q=fr/ media-gallery/detail/666/750

Euractiv (2019). The EU's digital tax is dead, long live the OECD's plans. https://www.euractiv.com/ section/economy-jobs/news/the-eus-digital-tax-isdead-long-live-the-oecds-plans/

Euractiv (2019). Why the EU leads in digital regulation, but lags in digital innovation. https:// www.euractiv.com/section/data-protection/news/ why-the-eu-leads-in-digital-regulation-but-lags-indigital-innovation/

Európai Bizottság (2018). Communication from the Commission to the European Parliament, European Council, the Council, the European Economic and Social Committee, the Committee of the Regions on Artificial Intelligence for Europe. Brussels, 25.4.2018 $\operatorname{COM}(2018) 237$ final. 4. https://ec.europa.eu/ transparency/regdoc/rep/1/2018/EN/COM-2018237-F1-EN-MAIN-PART-4.PDF

Európai Bizottság (2018). Communication from the Commission to European Parliament, European Council, the Council, the European Economic and Social Committee, the Committee of the Regions on Artificial Intelligence for Europe. Brussels, 25.4.2018 COM(2018) 237 final.1 https:// ec.europa.eu/transparency/regdoc/rep/1/2018/EN/ COM-2018-237-F1-EN-MAIN-PART-1.PDF

Európai Bizottság (2018). Questions and Answers on a Fair and Efficient Tax System in the EU for the Digital Single Market. https:// ec.europa.eu/commission/presscorner/detail/en/ MEMO_18_2141

Európai Bizottság (2018). Communication from the Commission to European Parliament, European Council, the Council, the European Economic and Social Committee, the Committee of the Region: Tackling online disinformation: a European Approach. COM/2018/236 final.
Európai Bizottság (2020). Az EU a közvetlen külföldi befektetések legfőbb globális célpontja. https:// ec.europa.eu/trade/policy/accessing-markets/ investment/

Európai Bizottság (2020). Investment. https:// ec.europa.eu/trade/policy/accessing-markets/ investment/

Európai Bizottság (2020). Package for fair and simple taxation. https://ec.europa.eu/taxation customs/general-information-taxation/eu-taxpolicy-strategy/package-fair-and-simple-taxation_en

Európai Bizottság (2020). Communication from the Commission to European Parliament, European Council, the Council, the European Economic and Social Committee, the Committee of the Regions: A European strategy for data. Brussels, 19.2.2020 $\operatorname{COM}(2020) 66$ final, 3.

Európai Unió Tanácsa (2019). ECOFIN Report to the European Council on tax issues. Brüsszel, 2019. december 9. https://data.consilium.europa. eu/doc/document/ST-14863-2019-INIT/en/pdf

Forbes (2020). The World's Most Valuable Brands (by Marty Swant). https://www.forbes.com/theworlds-most-valuable-brands/\#4ebe601e119c

IMF Staff (2018). Measuring the Digital Economy, IMF Staff Report, February 28. 2018

Javaslat - A Tanács irányelve a digitális reklámszolgáltatások nyújtásából származó bevételek után fizetendő digitális reklámadó közös rendszeréről. Brüsszel, 2019. március 1., 6873/19, 22. preambulum-bekezdés

Javaslat - A Tanács Irányelve az egyes digitális szolgáltatások nyújtásából származó bevételek után fizetendő digitális szolgáltatási adó közös rendszeréről \{SWD(2018) 81\} - \{SWD(2018) 82\} Brüsszel, 2018.3.21. COM(2018) 148 final 2018/0073 (CNS) 
KPMG (2020). Taxation of the digitalized economy, Developments summary. Updated: August 18

Marketing Land (2019). Almost 70\% of digital ad spending going to Google, Facebook, Amazon, says analyst firm. https://marketingland.com/ almost-70-of-digital-ad-spending-going-to-googlefacebook-amazon-says-analyst-firm-262565

Magyar Reklámszövetség (2020). 2019 MRSZ Média- és Kommunikációs torták, MRSZ barométerkutatás, 2020-as iparági prognózis. https://mrsz. hu/kutatas/media-es-kommunikacios-torta/2019mrsz-media-es-kommunikacios-torta-es-2020mrsz-barometer-

\section{NAIH/2015/2201/17/H. sz. határozat}

Növekedés.hu (2020). GVH-elnök: Önként és időben fizette be a gigabírságot a Facebook és a Booking.com. https://novekedes.hu/interju/gvhelnok-onkent-es-idoben-fizette-be-a-gigabirsagot-afacebook-es-a-booking-com

OECD (2014). „Broader tax challenges raised by the digital economy" Chapter 7. In Addressing the Tax Challenges of the Digital Economy. OECD Publishing, Paris, p. 14

OECD (2016). Big Data: Bringing Competition Policy to the Digital Era DAF/COMP/M(2016)14, 88. pont https://one.oecd.org/document/DAF/ COMP(2016)14/en/pdf
OECD (2020). What is BEPS? https://www. oecd.org/tax/beps/about/

OECD/G20 (2020). Base Erosion and Profit Shifting Project: Statement by the OECD/ G20 Inclusive Framework on BEPS on the TwoPillar Approach to Address the Tax Challenges Arising from the Digitalisation of the Economy, As approved by the OECD/G20 Inclusive Framework on BEPS on 29-30 January, https://www.oecd. org/tax/beps/statement-by-the-oecd-g20-inclusiveframework-on-beps-january-2020.pdf

Politico (2019). Trump slammed her as a U.S. hating 'tax lady'. She just got a promotion. https:// www.politico.com/news/2019/11/27/margarethevestager-eu-tax-promotion-074181

Reuters (2020). Facebook launches legal action against Irish watchdog over data transfers. https:// www.reuters.com/article/us-facebook-privacy/face book-launches-legal-action-against-irish-watchdogover-data-transfers-idUSKBN2621S6

Tax Foundation (2020). The U.S. Trade Representative Expands Its Digital Services Tax Investigations. https://taxfoundation.org/us-traderepresentative-ustr-digital-services-tax-investigations/

The Economist (2017). The world's most valuable resource is no longer oil, but data. https://www. economist.com/leaders/2017/05/06/the-worldsmost-valuable-resource-is-no-longer-oil-but-data 